Journal of the Society for the Study of Architecture in Canada Le Journal de la Société pour l'étude de l'architecture au Canada

\title{
A Storm of Controversy Over Toronto's Legislative Buildings
}

Debora Booth Alcide

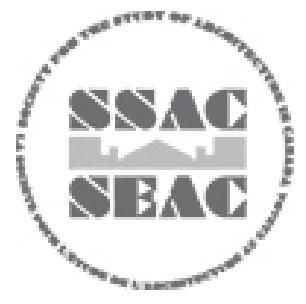

Volume 45, numéro 2, 2020

Chercheurs en émergence

Emerging Scholars

URI : https://id.erudit.org/iderudit/1076485ar

DOI : https://doi.org/10.7202/1076485ar

Aller au sommaire du numéro

Éditeur(s)

SSAC-SEAC

ISSN

2563-8696 (numérique)

Découvrir la revue

Citer cet article

Alcide, D. B. (2020). A Storm of Controversy Over Toronto's Legislative Buildings. Journal of the Society for the Study of Architecture in Canada / Le Journal de la Société pour l'étude de l'architecture au Canada, 45(2), 27-37.

https://doi.org/10.7202/1076485ar d'utilisation que vous pouvez consulter en ligne. 


\section{A STORM OF CONTROVERSY OVER TORONTO'S LEGISLATIVE BUILDINGS}

DEBORA BOOTH ALCIDE is a third-year Ph.D. student at York University. Her present field of study focuses on Romanesque Revival architecture in Ontario and its place in the architectural repertoire of the last half of the nineteenth century. Prior to her current field of research, she has concentrated on the Romanesque art and architecture of the Bourgogne-FrancheComté region of France. In addition to her studies at York, Debora is faculty at Toronto's Humber College of Applied Technology, where she teaches art, history, and design.

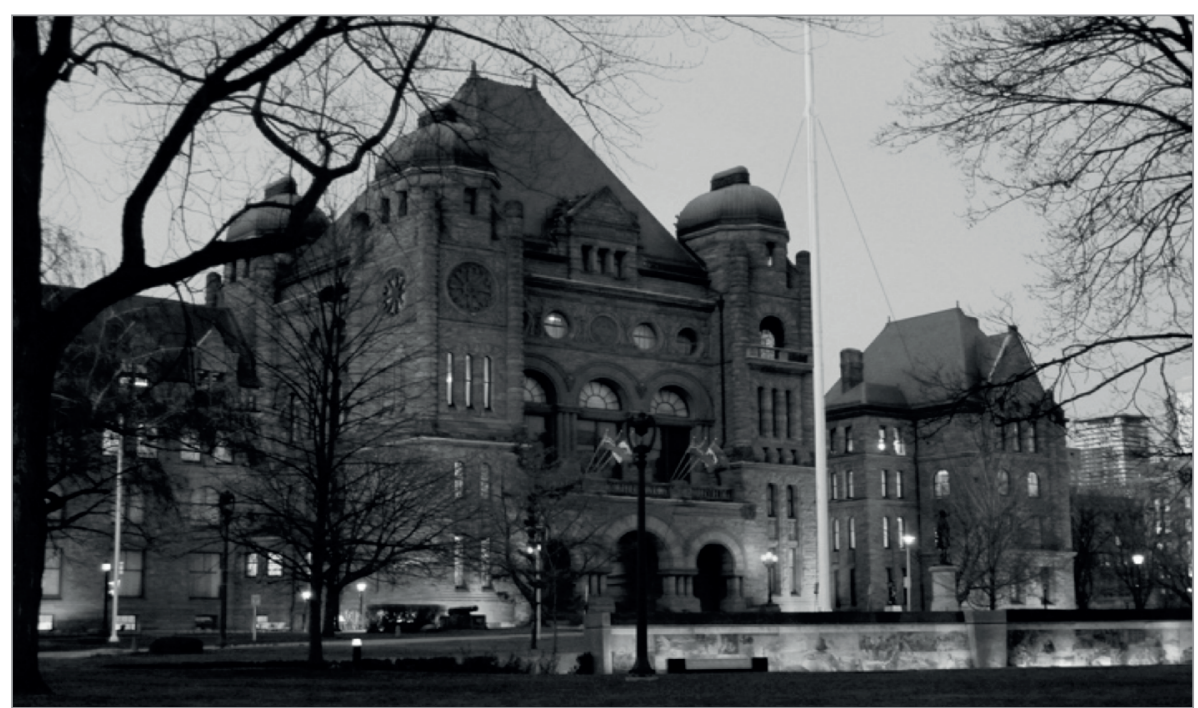

FIG. 1. QUEEN'S PARK LEGISLATIVE BUILDING IN THE PRESENT DAY. | DEBORA ALCIDE, 2019.

\section{$>$ DEBORA BOOTH ALCIDE}

Cince the inauguration of York as a $\checkmark$ colonial outpost, the city has seen four purpose-built parliament buildings. York's first was destroyed by enemy action in the War of 1812, the second was lost to fire, the third fell into ruin, and the last and most controversial is still serving Ontario's legislature today (fig. 1). Although now surrounded by the city, the Legislative Buildings once delineated the limits of the downtown core. Dominating Queen's Park, the legislature still dominates its hilltop position, undiminished by the city's skyscrapers. The now familiar and reassuring landmark created more derision and scandal than perhaps any other Canadian building in the nineteenth century. A quote by an anonymous writer in The Canadian Architect and Builder sums up the criticism this building ignited: "The building as one that will, if erected according the design as shown, be one of the ugliest and most inartistic buildings erected on this continent, or for that matter, any other continent, during the last ten years."1

Controversy began from the first suggestion that a new building was needed, and it did not abate until long after construction was finished. Why did this one building designed by an American architect garner such a furor of acrimony among the architects of Ontario and the general public, and what were the resultant ramifications of the botched search for a design to architectural practices in the province?

This paper explores these questions by examining the evolution of the Legislative Building at Queen's Park, highlighting 


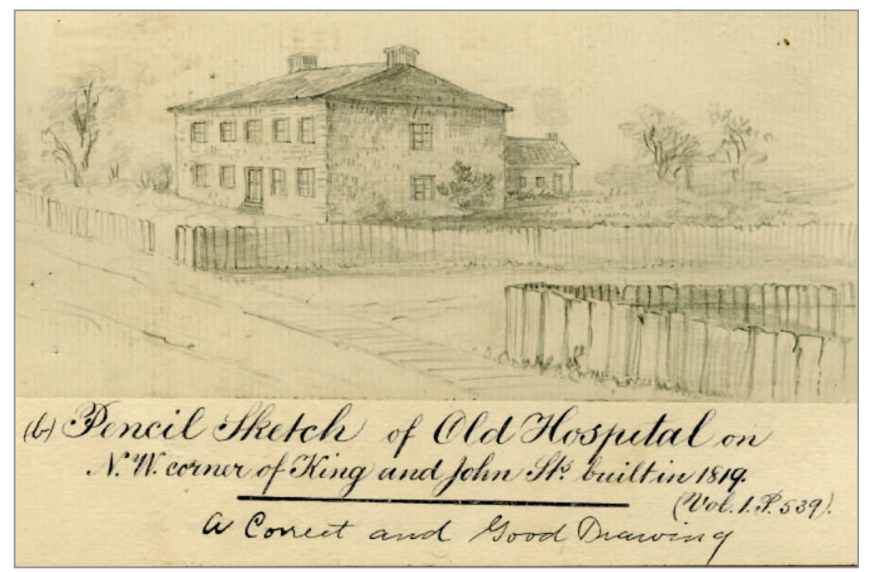

FIG. 2. THE NEWLY BUILT HOSPITAL, USED FOR PARLIAMENT FROM 1824 TO 1829. | COURTESY OF THE TORONTO PUBLIC LIBRARY, TEC 356A.

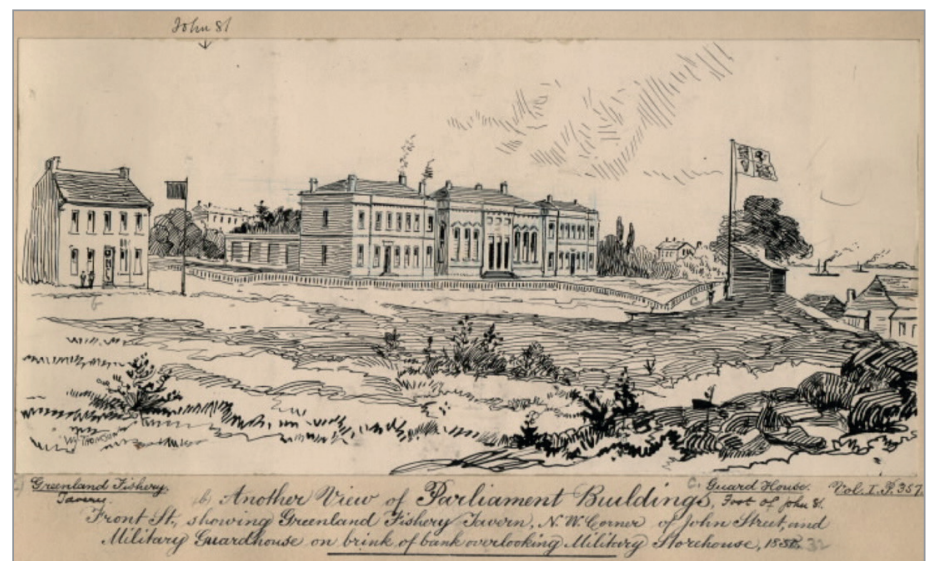

FIG. 3. FRONT STREET PARLIAMENT BUILDING, 1841, BY WILLIAM THOMAS, INCLUDING THE NEVER-BUILT PLANNED GRAND PORTICO. | COURTESY OF THE TORONTO PUBLIC LIBRARY. the men and events that both facilitated and hindered its eventual materialisation. It also highlights the problems that Ontario's architects faced in their competitive field, in particular the belief that homegrown architects were somehow inferior to their American counterparts. The eventual decision to hire an American for Ontario's most important building served to generate the rallying call that united the province's architects in a common cause. Ultimately, this paper will demonstrate that this one building forever changed the way the profession was practiced, applied, and eventually perceived in the province.

There is a strong case to be made that the creation of the Ontario Association of Architects (OAA) in 1889 was an inevitable outcome of the disputes surrounding Queen's Park. Changes to architectural practice in Ontario would have happened eventually, but it was this building that galvanized the architects of Ontario to act in unison. The province's architects felt compelled to regulate their practice and close the loopholes that allowed foreign, and more specifically American competition for work they deemed should be locally awarded. This paper will briefly delve into Upper
Canada's 1832 Legislative Building, before broaching the complicated and intriguefilled process to find an architect and design for the building we see today. The research is aided by opinions expressed in The Canadian Architect and Builder, newspaper articles, and government correspondence. They help to piece together the tangled web of subterfuge and possible nepotism that contributed to the finished design of Queen's Park. Opened to great fanfare in 1906, the building's rocky start is a study in mishandling of all the parties concerned in its creation. The true story of the events and all the players may prove impossible to establish, nevertheless, it is a story worth telling.

\section{PARLIAMENT BUILDINGS \\ PRIOR TO QUEEN'S PARK}

The formerly named Palace of Government was the first purpose-built structure to house the legislature of Upper Canada, but this modest structure was burned down by the Americans in 1813. The building that replaced it looked more like an elegant country house, but this too was destroyed by a chimney fire in 1824, with the loss of valuable records. The intervening three years between the fire and the new construction found the legislature occupying the new, but still unoccupied hospital (fig. 2). ${ }^{2}$ The temporary nature of this arrangement emphasized the need for new premises.

As early as 1826, Kingston architect Thomas Rogers [1788-1853] was asked to draw up plans for the new premises, but his 1832 completed design exceeded the projected budget, so the construction plans halted until 1833. In the interim, Parliament took over the courthouse, which proved an unsatisfactory solution. ${ }^{3}$ Finally, in 1833, construction began, with Rogers's plan generally accepted as the design used; however, the origin of the final design is somewhat murky. ${ }^{4}$ Construction continued through to 1836 , with many architects seemingly becoming involved with the finished building: Samuel George Curry [1854-1892], James G. Chewett [1793-1862], John G. Howard [1803-1890], and John Ewart [1788-1856]. ${ }^{5}$ Rogers found the commute from Kingston problematic for supervising construction, so Chewett took over the supervisory role and Howard continued to modify the interior. Unfortunately, Rogers's planned grand portico (fig. 3) was never built, which left the existing structure's façade lacking in majesty, giving it an incomplete appearance. 


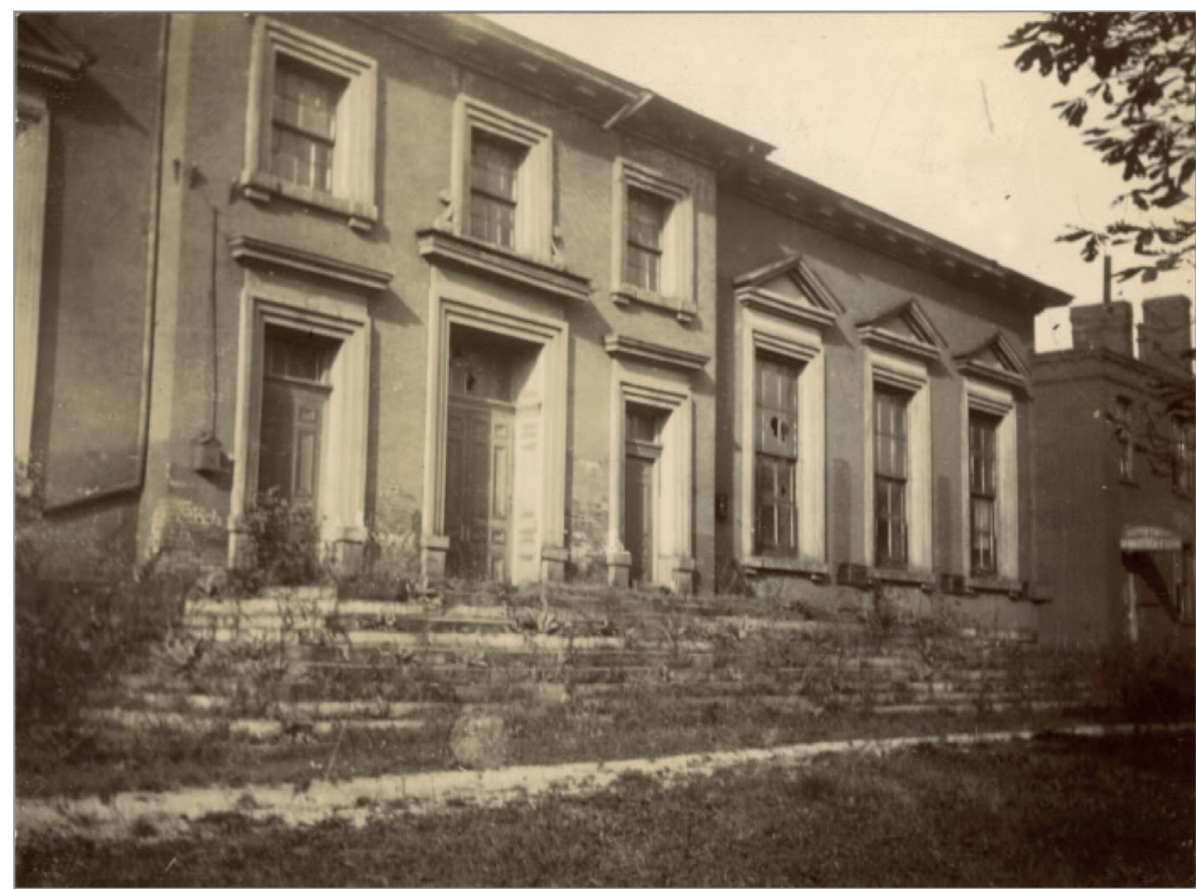

FIG. 4. EXTERIOR OF THE PARLIAMENT BUILDING (1832-1893) SHOWING ITS DILAPIDATED STATE IN A PHOTOGRAPH OF 1890. COURTESY OF THE TORONTO PUBLIC LIBRARY, TEC $369 Z$.

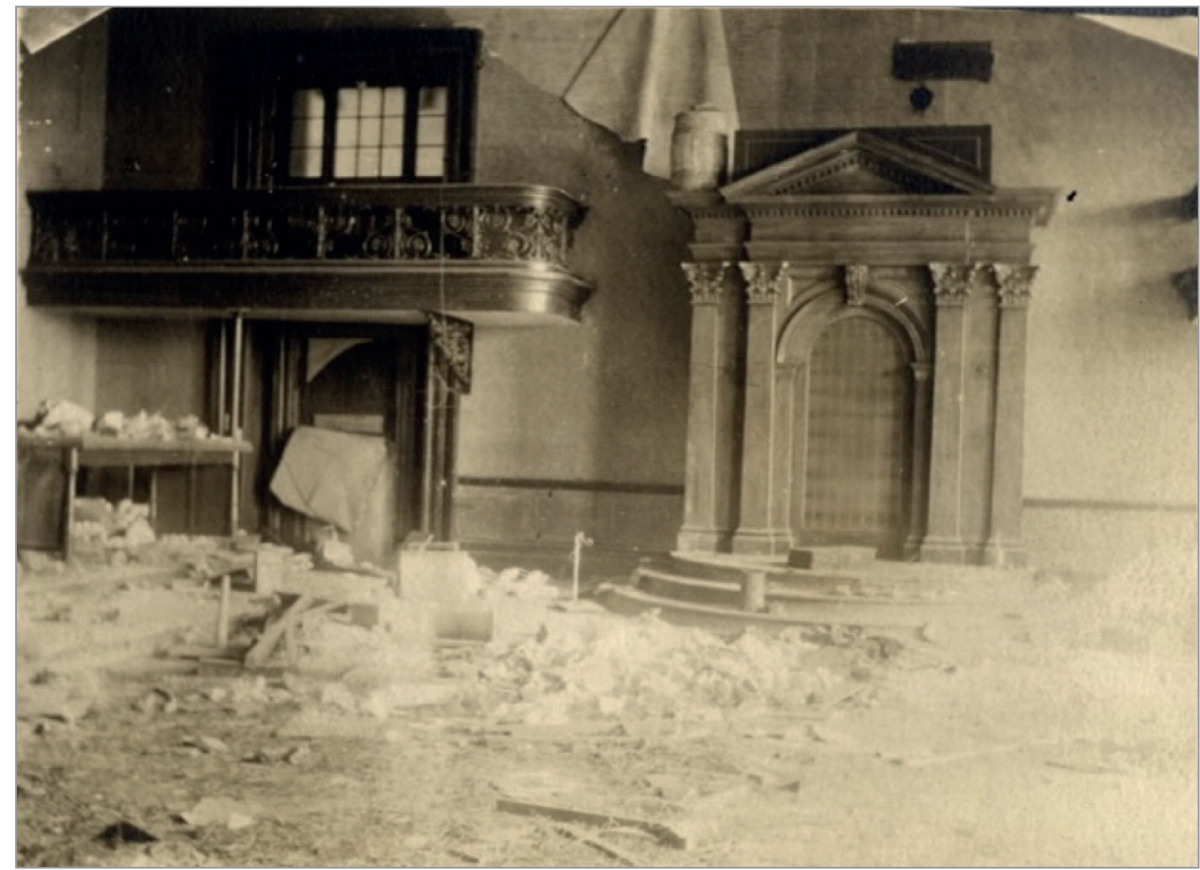

FIG. 5. INTERIOR OF LEGISLATIVE CHAMBER (1832-1893), PHOTO TAKEN IN 1890. | COURTESY OF THE TORONTO PUBLIC LIBRARY, TEC 369E.
The façade was Georgian, mimicking the city's dominant building style; however, the final project, like its predecessor, received scathing criticism at its inception, a fate that was to multiply tenfold with the future legislative building. ${ }^{6}$ The faults found in this construct were wrongfully attributed to the architect, who was unrealistically restrained by funding and the constant changes required by the overseers of the project. ${ }^{7}$ Well situated and adequate for the present, the building would not suffice for the rapidly expanding city and future needs of Ontario's Parliament.

This building sporadically served Parliament from 1833 until 1893. In the years that Parliament vacated for other locales, the building was used as an insane asylum and a military barracks. This sporadic occupancy by government hastened the building's deterioration and worsened the already high upkeep expenses. The astronomical cost of running Parliament left only one rational solution; a new building was needed. Photographs of the Georgian structure (figs. 4-5) clearly show its dilapidated state; one of the greatest fears was fire, which had destroyed not only Toronto's Legislative Building, but also those in Quebec City and Montreal. The previous fire of 1824, still within recent memory with its tragic loss of records, was a constant apprehension, particularly since the building housed forty-five open grates and fifty stoves. ${ }^{8}$

Throughout the 1870s, action was not forthcoming, even with several critical reports detailing the many issues by the chief of works, Irish-born architect and engineer Kivas Tully [1820-1905]. Reading between the lines of Tully's polite criticism, we can safely surmise that the building was a dangerous health hazard and a fire trap. ${ }^{9}$ Its position on the lake, 
amplified by the lack of proper air circulation, likely contributed to a mould accumulation. This left the building rather foul smelling and perhaps gave the politicians the impetus to get things rolling. Tully's reports and most assuredly the odour eventually roused the parliamentarians to action. On February 26, 1880, a decision was finally reached, and a bill was passed to rebuild.

\section{THE SEARCH BEGINS} FOR A NEW DESIGN

The land that the Parliament Building presently occupies was originally part of King's College, now the University of Toronto. As early as 1854, land had been leased to the city by the University for a period of 999 years, with the provision that land be reserved for the Legislative Building. What is not entirely clear, is why the University insisted that the land be put to parliamentary use. The likely motive came from a proviso the University added to the agreement, which specified that ten thousand dollars above the initial outlay for the Legislative Building's construction costs be allotted for a new examination building, improved classrooms, and funds for their museum, now Toronto's Royal Ontario Museum. ${ }^{10}$

In February of 1880, Tully, as a respected and accomplished architect, approached Christopher Findlay Fraser [1839-1894], Ontario's Commissioner of Public Works, with his ideas, as well as his own designs for the desperately needed new premises. Commissioner Fraser would become a prominent figure in the reconstruction of the Legislative Building, and he was, and remained, a powerful and influential force in Sir Oliver Mowat's [1820-1903] liberal government until his early death. Covering any eventuality, Tully drew up two distinctively different plans, of which only two elevations survived (fig. 6). ${ }^{11} \mathrm{He}$

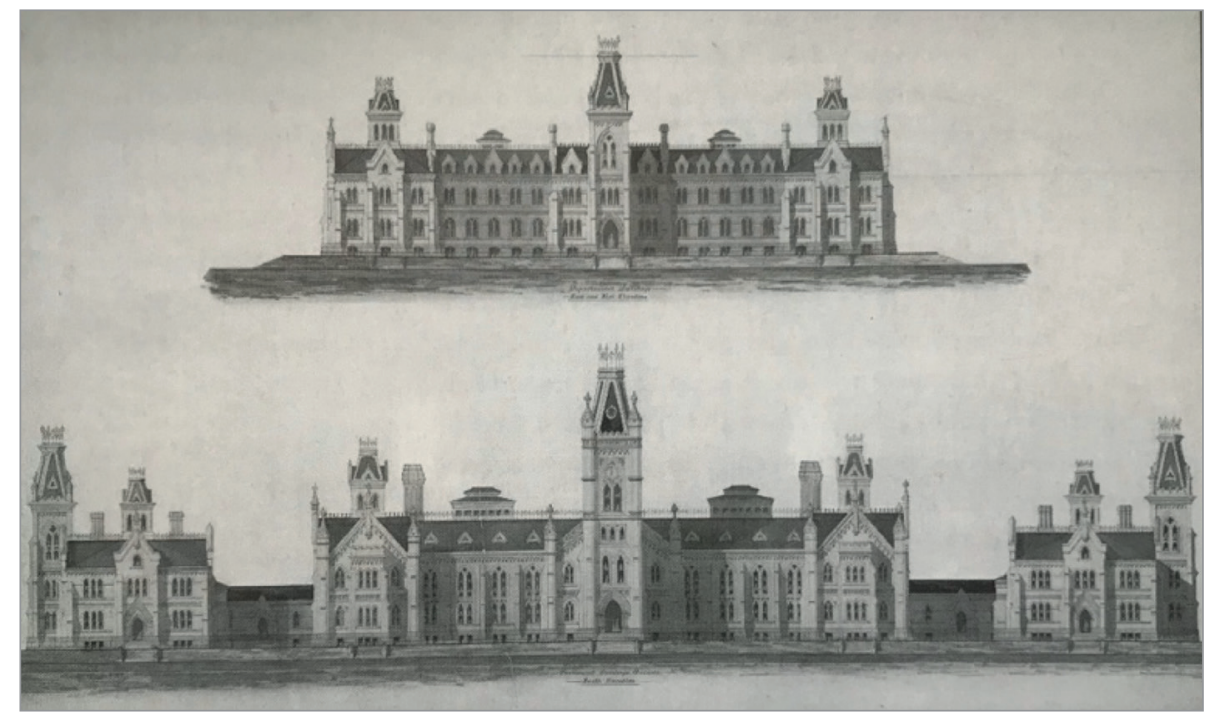

FIG. 6. TULLY'S UNEXECUTED ALTERNATE GOTHIC AND BEAUX-ARTS DESIGN, SUBMITTED TO COMMISSIONER OF WORKS CHRISTOPHER FINDLAY FRASER AS A POSSIBLE DESIGN FOR THE MUCH-NEEDED NEW PARLIAMENT BUILDING. | ARCHIVES OF ONTARIO, RG 15-13-2-80.

added his justifications for one design over another based on cost, something that obviously drove the interests of the government. It seems that he favoured his Classical design, but countered his preferred choice with a Gothic proposal, which he felt could be produced more frugally, while providing better light and ventilation. ${ }^{12}$

His recommendation of the Gothic style seems to have been a calculated bet to appeal to the fiscally minded Fraser. In his justifications, he critiques the design of Sir George Gilbert Scott's [1811-1878] original Gothic Revival design for the London Foreign and War Offices in the 1860 s, as being too showy and pandering to the philistine tastes of the architecturally uneducated..$^{13}$ However, with a commission in the offing, he abandoned his principles and went with the most likely design to win over the fiscally minded commissioner. No evidence exists to explain Fraser's rejections, but it was likely the half-million-dollar construction estimates that swayed his decision. Unfortunately, without floor plans we cannot establish its functionality, but we know he specified the overall dimensions, the outlay of the rooms, their various functions, and its excellent accessibility to the downtown hub.

Tully had obviously put a great deal of cost and effort into creating these drawings and specifications, which leads us to think that he was confident of his appointment to take over the project. According to Eric Arthur [1898-1982], recounting the event, Tully placed economic concerns before design, but it is unclear on what criteria he determined Tully's deficiency in design efforts that he described as "on the lowest level of architectural thought." ${ }^{14}$ At the time, the halfmillion-dollar construction costs were the main concern of the financially unsound government, so Tully's plans were put on the back burner and thoughts of a new building were halted until 1880, when an open competition for a design was initiated. Interestingly, in Tully's rationalization for his designs, his mention of the 


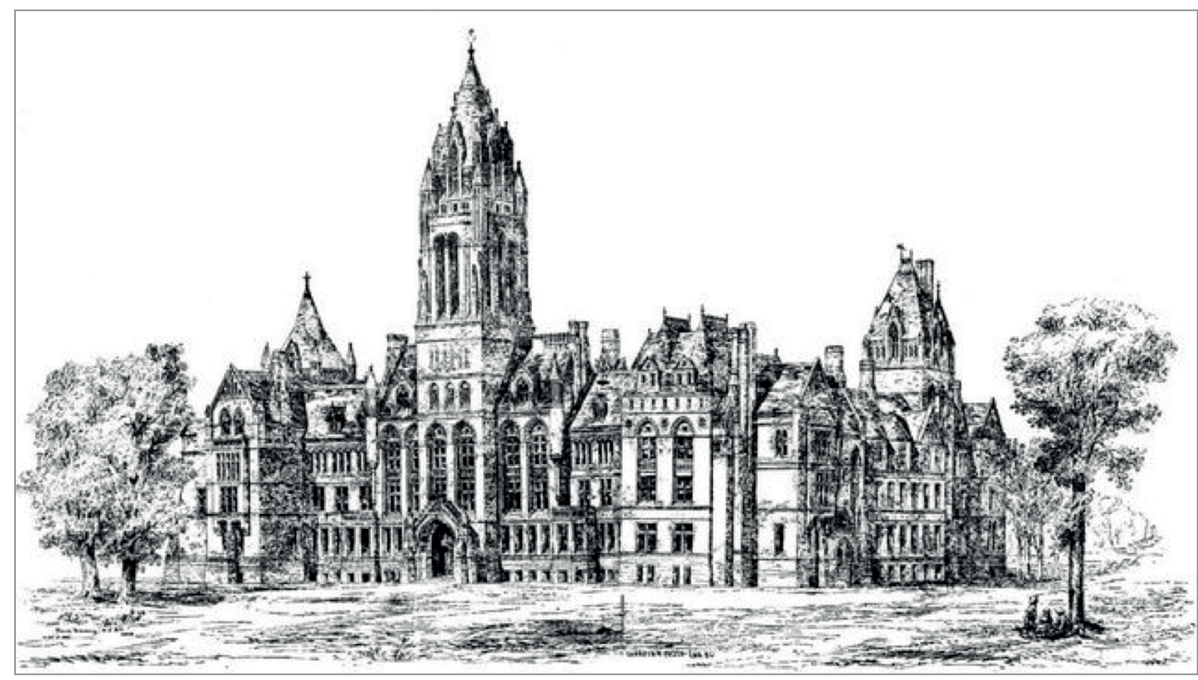

FIG. 7. DARLING \& CURRY'S PROPOSAL FOR THE ONTARIO LEGISLATIVE BUILDING, THE WINNING DESIGN THAT WAS NEVER BUILT. | FROM THE CANADIAN ARCHITECT AND BUILDER, 1889, VOL. 2, NO. 1, PLATE 1A. COURTESY OF RARE BOOKS AND SPECIAL COLLECTIONS, MCGILL UNIVERSITY LIBRARY.

competition for the British government buildings eerily foreshadowed a similar fiasco with the Toronto competition. Tully's failure to secure the commission meant that the search should continue to find a design fitting Ontario's most significant provincial building, but most importantly, one that came in on budget.

\section{COMPETITION TO FIND}

\section{AN APPROPRIATE DESIGN}

In April 1880, the prestigious competition was widely publicized in Canada, as well as in the newspapers of Chicago, Boston, and Buffalo. Very specific criteria were laid out for the architects, including size, room functionality, and all interior and exterior specifications. This would prove a costly and time-consuming undertaking for any firm that decided to enter the fray. The jury chosen consisted of the federal commissioner of Works Alexander Mackenzie [1822-1892], Buffalo-based architect Richard A. Waite [1848-1911], and the well-known Toronto architect, William G. Storm [1826-1892]. For the amount of preparatory work required, the remuneration was meagre. First, second, and third prizes were two thousand, one thousand, and five hundred dollars, respectively, certainly not a monetary gain for the winners, but a prestigious one, if successful. By the official deadline of October 15, 1880, sixteen applications were received, eleven from Canada and five from the United States.

The initial deliberations took a month. The judging criteria to ascertain a winner included the cost, general arrangement, architectural merit, interior lighting, heating, ventilation, drainage, and sanitary considerations..$^{15}$ In the area of architectural merit, the Toronto firm of Darling and Curry led with an impressive Gothic design (fig. 7). The firm had put a great deal of effort and thought into this proposal. In the late 1820 s, they designed an entry for an earlier competition that never came to fruition, so they were already cognizant of the functional needs of the government. Their realistic, over-budget cost estimate quickly ended their hope for first place, which then passed to another Toronto firm, Gordon and Helliwell. Although their design did not survive, Tully described it as having a domed legislative assembly, which indicates that the design was Classical rather than Gothic. Another design was anonymously submitted by the architect of Ottawa's east and west blocks of the parliament buildings, Augustus Laver (fig. 8), but it too failed to meet the standards the government required. ${ }^{16}$ All bids were kept for future reference, with the government retaining the rights to them for a meagre four hundred dollars. Their retention by the government may have influenced the eventual design of the building we see today. ${ }^{17}$

At this juncture, the competitors were still anonymous to the judges, a fair and practiced policy within Canada. The jury praised the Darling and Curry design, while chastising the government for their inadequate funding proposal, which nullified its win. Indecision to come up with a clear winner led to a stalemate. To rectify the situation, six of the entrants were asked to revise their plans, presumably with an intent to lower the estimated building cost. Two designs were sent out for tender, Darling and Curry's and Gordon and Helliwell's, hopefully to produce a construction estimate that fell within the budget of half a million. The cap for building costs was determined by Tully's previous 1880 design estimate of half a million. The not surprising result was that both came back over budget, with Curry and Darling's at six hundred and twelve thousand dollars and George and Helliwell's at five hundred and fortytwo thousand, with both quotes provisioned by the same firm of Brown and Love Contractors. ${ }^{18}$ This should have raised a red flag to the government, if not, at least to the architects involved that the two bids came from the same contracting firm and equally over budget. It should be noted that this was the firm that eventually 


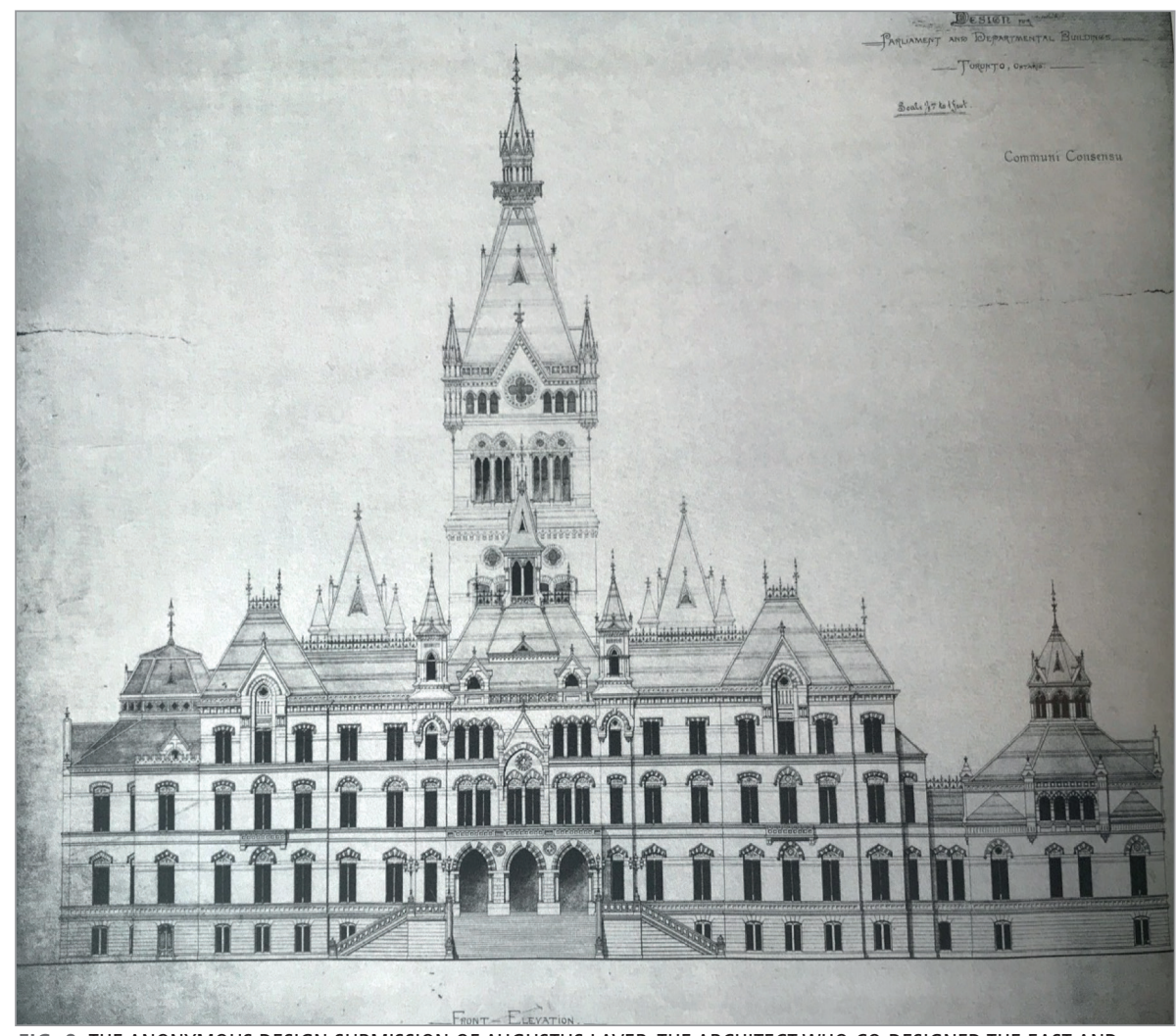

FIG. 8. THE ANONYMOUS DESIGN SUBMISSION OF AUGUSTUS LAVER, THE ARCHITECT WHO CO-DESIGNED THE EAST AND WEST BLOCKS OF OTTAWA'S PARLIAMENT BUILDING. | ARCHIVES OF ONTARIO, RG 15-13-2-164.

received the project, leading one to suspect that it was already a fait accompli on the part of the government, particularly considering that the eventual cost was almost double their original estimate. Both designs coming in over budget should have also been a clear indication to the government that their cost expectations were unrealistic. The result, once again a stalemate, all plans were put on hold.

\section{STALEMATE IN THE} SEARCH FOR A DESIGN

In the general election of 1883 , the cost of the new building was one of the most sensitive issues and this stumbling block interrupted the momentum of the project, if it can even be labelled a momentum... it was more of an impasse. Finally realizing that funding was inadequate, Fraser initiated a bill to raise it to seven hundred and fifty thousand dollars, which scraped by on March 23, 1885. ${ }^{19}$ It should be noted that this was well over the six hundred and twelve thousand estimate for Darling and Curry's winning design, and now inflation had to be considered. The whole affair was about to turn very sour, where fair play and prior agreements were blatantly ignored, and the rights of the winning architects were totally disregarded.

The shenanigans surrounding the competition set into motion events that would ricochet for years, igniting both private and public indignation over the eventual choice of a design and architect. It also created a contempt for the entire process of using competitions to decide the best design. The aftermath of this competition proved to be the final blow that spurred the competitive and generally disassociated architects of Ontario, to finally work together to create an association that had the power to regulate and professionalize the way architecture was practiced in the province and to restrain, or even more desirable, eliminate foreign incursions into their field.

\section{FRASER TAKES CONTROL}

Now that the funds had been increased, the government was faced with a dilemma, so Fraser took it upon himself to find the solution for his pet project. Unfortunately, Fraser had not read the room correctly. He was either oblivious to, or chose to ignore the proper and time-honoured tactics of dealing with architects. Fraser's blunders in dealing with the architects involved aroused enormous animosity among many of Ontario's highly respected architectural firms and practitioners, who were already cognizant of the missteps sanctioned by the government.

Financially, the firms involved had invested an enormous number of man-hours to not only draft every aspect of the new build, but to prepare the specifications, a major undertaking for a building of this size and complexity. This is a condition that would normally not be attached to a search for the best design in the initial process. Even as late as 1886, the government still planned to go with one of the winning designs, but Fraser took it upon himself to ask Waite, the Buffalo architect, to re-examine and recommend one of the two winning plans.

This is where intentions on the part of Fraser become suspicious, the original jury was not privy to this re-examination. In 
all fairness to Fraser, his elimination of the two original jury members could be rationalized on his part. Mackenzie, as federal commissioner of Works, was not an architect; he was a former contractor and he may have been unqualified to arbitrate the design elements of the building, but he was more skilled in the technical and functional aspects needed. Storm, although a well-established and competent architect, could not be an impartial judge, since the participants were all either colleagues or friends of his. This appeared to leave Waite as the sole adjudicator for the reappraisal. The American architect was on friendly terms with many government officials, including Commissioner Fraser, and this familiarity was guaranteed to arouse suspicions of collusion by the disgruntled losers. ${ }^{20}$

Fraser, the man responsible for seeing the project to completion, was trained as a lawyer, so it was natural that he would accept the more studied architectural judgement of his acquaintance Richard Waite, but it is dubious and arouses suspicion as to why Storm, or at least another architect of good standing, was not brought in for a second opinion. Perhaps, once again, it was a cost-saving move, to eliminate any further fees that another architect would demand for his review. Nevertheless, unless we become privy to the private conversations between Fraser and Waite at that interlude, we will never know if Waite's eventual commission was nepotism, or simply a matter of efficacy on Fraser's part to get the job completed.

If there was collusion behind closed doors, it was likely not instigated by Fraser, seemingly a politician of integrity, but we cannot dispel the idea that Waite on the other hand saw this as a golden opportunity. Crossman aptly points out that Waite, although not an original architect, was an enterprising one, using his contacts from the 1880 competition to secure commissions in Canada and Buffalo. ${ }^{21}$ The adjudication of the competition aroused the ire of the prominent architects in the province, primarily because Waite, an American, seemed to be the deciding vote and he had found fault with every entry. ${ }^{22} \mathrm{His}$ critique centred on deficiencies he found with heating, lighting, and ventilation, all items that could be addressed by the architects, if given the chance, which they were not. In all fairness, the government, as well as Tully, Ontario's chief architect, had also weighed in on the unsuitability of the two designs, but he never voiced criticism of the actual design of the buildings, simply the floor plan layout. ${ }^{23}$ The plans could be adjusted, it was the design that should have been the deciding factor for the government, but it seems to now have taken second place; function over form, but more likely expense over form.

The minister of Works was eager to get the building underway, so Waite was likely the expedient choice to appoint as judge and jury. Fraser probably rationalized that an American was an impartial voice, after all, he had not tried to enter the competition himself, he was detached from local politics, and he was not a member of the architectural societies of Toronto. Waite did get the commission from Fraser, but it appears as if his decision was already a foregone conclusion. Waite had promised his deciding reappraisal of the two plans within a week. A week could only facilitate a cursory glance and certainly not a thorough and detailed examination that something of this import and complexity should garner. The plans consisted of hundreds of pages of drawings as well as specifications, so studying each set of plans was a time-consuming and detailoriented enterprise that would not only require compensation for the hours of work involved, but an exhaustive study.

\section{ARCHITECT WAITE} TAKES CONTROL

Waite's promised decision was put into limbo for over eight months, much to the displeasure of Fraser. Here is where the possibility of collusion on Waite's part may well have started to circulate. When Waite's reply finally arrived, he dismissed both designs as "unsuitable and defective," but with little justification for his decision, leaving Fraser still without a design. Fraser was now in an untenable position. ${ }^{24}$ The politician's handling of the situation and in particular his treatment of the architects involved were secretive and inherently cowardly. His subterfuge springs from his awareness that once the news of his decision was made public, he would find himself at the centre of a storm of controversy, from not only the opposition party, but also the architects of the city. The firms of Darling and Curry and Gordon and Helliwell were not only kept in the dark about the rejection of their plans, but they were not informed either of Fraser's solo decision to employ the services of Waite. ${ }^{25}$ Darling, hearing the rumours of Waite's appointment, directly confronted Fraser in writing, but he failed to receive a response. ${ }^{26}$ Almost two months passed before Fraser, under mounting pressure, announced to the legislature Waite's disapproving evaluation and his intention to hire the same Buffalo architect. He justified his decision based on Waite's past successes with earlier buildings and his initial appointment as a jury member. It is more likely expediency on Fraser's part, as he wanted the building to be erected quickly, and further examinations of the designs, or even a new competition that was suggested, would put the project off for years... with mounting costs.

Even if the intentions of Fraser and Waite were unbiased and not self-serving, the 
way the whole affair was conducted was unfair, deceptive, and ethically reprehensible. Arthur aptly delineates the fiasco: "this writer knows of no competition where an analysis by competent critics revealed incompetence in high places, a total disregard for professional ethics, and, unbelievable when stated, a wholly insensitive, cruel, and indefensible treatment of the successful competitors." 27

The criticism continued to escalate, with volumes of bitter and venomous commentary surfacing in print. One journal, The Canadian Architect and Builder, that began publication after the awarding of the contract to Waite in 1888, was one of the prime vehicles to spread the derision and it quickly became a leading voice for many of Canada's, and particularly Toronto's architects. In 1889, closely related to the journal's launch, we see the beginnings of the Ontario Association of Architects. The birth of these two entities, after the announcement of Waite's windfall, was not mere coincidence. Not surprisingly, the first three presidents of the OAA-Storm, Curry, and Darling-were architects intimately embroiled in the Legislative Building controversy. Storm was a partner in the prestigious firm of Cumberland and Storm and a jurist in the initial competition, while the latter two were partners in the firm that won first prize. The interconnectedness of the principal players, the journal, and the OAA was glaringly obvious, which adds fuel to the suggestions of unfair dealings and nepotism.

The Canadian Architect and Builder became the most vocal arena of criticism directed against Waite and the eventual design he produced. Absurdly, the commission was awarded to Waite without any scrutiny or oversight as to design or cost, the two elements that eliminated the former applicants for the design.
From the outset, he seemed to have been given free reign by Fraser, although the commissioner did lay out very precise contract specifications; when considering their restrictiveness, it seems surprising that Waite agreed to them. We can only speculate that he believed it would be a fortuitous opportunity and hopefully a lucrative one. If he was to receive the normal percentage allotted to the architect for an eventual outlay for the building at five percent, it would all be worthwhile; however, if he was only awarded the fee outlined in the original building estimate, he stood to lose a great deal. By his acceptance of the job, we can only presume he banked on the former. The final construction cost at one million two hundred fifty thousand dollars was almost double Darling and Curry's initial design estimate. As an architect who had already worked in Canada, Waite must have had some prior knowledge of the final cost of the build. Hindsight of the project's eventual outcome and his lengthy battle for compensation would likely have prompted Waite to turn down the project. It became a nightmare of litigation, increased demands, and constant interference from Fraser, who persistently fought Waite over his commission fees and requests for payment of services rendered. All that documentation is saved in the Legislature's departmental records and mimics the same issues that befell Curry and Darling's firm when trying to seek remuneration, which never came to fruition. ${ }^{28}$

Once Waite had been appointed by Fraser, no redress, or even compensation was available for the snubbed winners of the competition; a deplorable mishandling of the architects involved. Fraser seemed to have no knowledge of how architects conducted business, either fiscally or ethically. We can certainly sympathize with the Canadian architects' vitriolic criticism, liberally voiced and certainly not without justification. Five years after the results of the competition, Curry and Darling, and Gordon and Helliwell had still not received their prize money, and Curry and Darling never received any payment for their revised plans. Arthur aptly pointed out: "A surer way of putting an architect in bankruptcy can hardly be devised." 29 Drawing up plans including specifications was a time-consuming and expensive operation. The stakes were high, and these two firms were gambling on a win; unfortunately, they had much to lose financially.

In the interim, Waite had almost a year to formulate his design, and it should be noted that he had first-hand knowledge of all the previous entrants' designs and specifications, as well as the rationalization for their rejection. The lapse of time involved for him to acknowledge the unsuitability of the two Canadian designs, and the subsequent appearance of his own plans appear highly suspect. He pleaded illness for the delay, but it also gave him enough time to produce his own drawings. He designed a muscular Romanesque Revival building that was Richardsonian in its conception and bore no resemblance to the earlier winning designs (fig. 9). Henry Hobson Richardson's [1838-1886] designs were already a trademark style in America in the 1880 s. It rapidly became the commercial and governmental style until the turn of the century, but Gothic Revival seemed more in keeping with the very British makeup of Toronto. Victoria College built in 1857, a stone's throw away, was perhaps a model of the Romanesque Revival style that may have served as an inspiration for his medieval revival choice, although his 1875 home built for a Buffalo liquor magnate has many features that were enlarged and elaborated on with Queen's Park. 
It should also be mentioned that the Romanesque Revival style was then considered more of an American direction in design, the earliest Canadian adoption of Richardsonian architecture was the Sherbourne Street Methodist Church, 1887, by Langley and Burke. However, it did not become a popular lexicon in Toronto's architectural vocabulary until the 1880s. Canadian tastes were more closely aligned with Gothic Revival very popular in Britain, as opposed to the Classical and Romanesque Revival styles popularized in America. Waite's massive and solid-looking design was touted to the legislature by Fraser, who stressed his placement of the legislative chamber, which was nestled within the east and west blocks. ${ }^{30}$ Fraser derogated Darling and Curry's design, which placed the chamber in the centre of a quadrangle, undoubtedly reiterating Waite's observations that stressed the disadvantages of the latter's design for its inadequate ventilation and fireproofing. ${ }^{31}$ Ironically, both of these labelled defects of the other designs befell Waite's own building. To this day, the ventilation of the building is atrocious in all seasons, and Waite, the self-described fireproofing design expert, had two of his Buffalo buildings and half of the Toronto Legislative Building go up in flames.

\section{CONSTRUCTION BEGINS, BUT} CONTROVERSY DOES NOT ABATE

Construction finally began in the summer of 1886, but the controversy did not abate. The Canadian Architect and Builder continued to rail against the design and the architect. Curiously, the publisher C.H. Mortimer [1888-1908] is known to us, but the editor and his many rants remain elusive. It is this curious situation that piqued my curiosity. My suspicion has always been that the editor was one of the initial winners of the

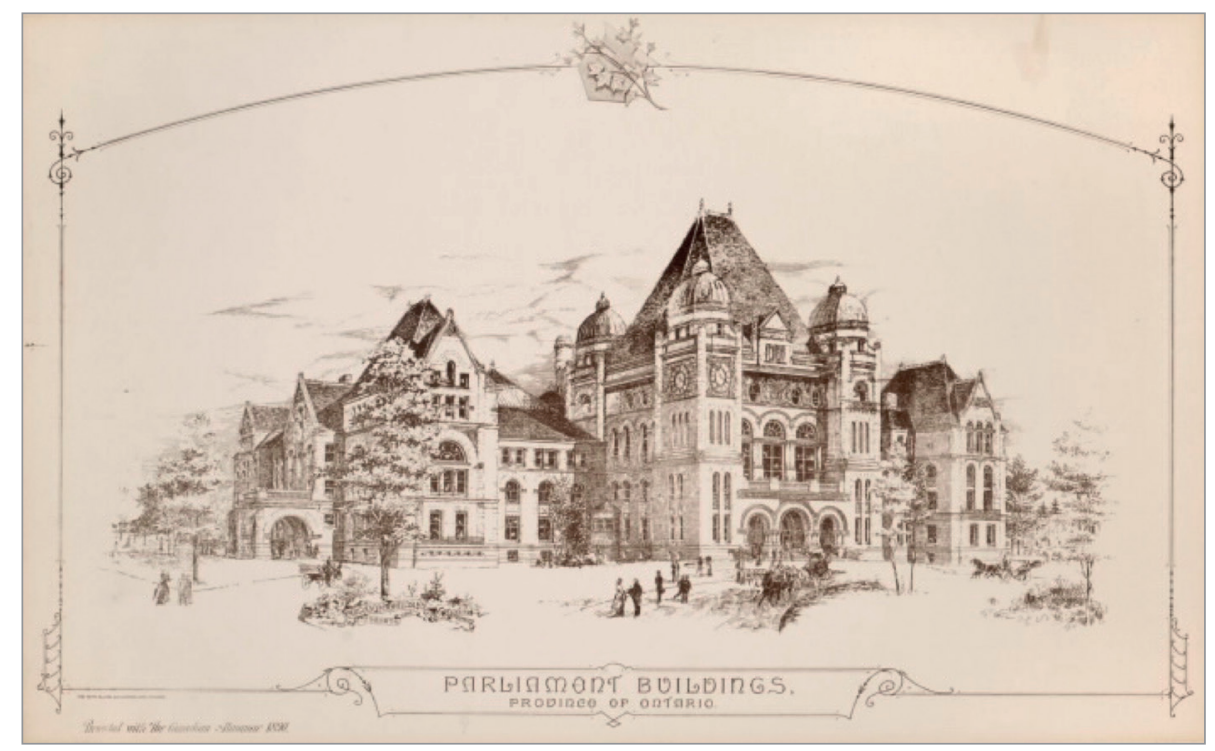

FIG. 9. PARLIAMENT BUILDING CONCEIVED BY RICHARD WAITE AS THEY APPEARED IN 1893, BEFORE THE FIRE OF 1909 THAT ENTIRELY CHANGED THE WEST WING. | COURTESY OF THE TORONTO PUBLIC LIBRARY.

competition, narrowing down just whom it might be was aided by the sleuthing of Robert G. Hill, architect, FRAIC [Fellow of the Royal Architectural Institute of Canada], and editor of the Biographical Dictionary of Architects in Canada. His searching revealed that the office for submission of articles was 31 King Street West, which likely had an editorial staff, because Mortimer also published another journal, Dominion Mechanical \& Milling News. Robert Hill and I both surmise that the articles were written by someone with an advanced knowledge of architecture, which rules out Mortimer. I believe that the editor is either Samuel G. Curry, or his partner, Frank Darling [1850-1953], the chief architects in the firm that won the original competition. It is also worth noting that their office was literally around the corner from Mortimer's office. After Curry retired from architecture in the late 1920s, he turned his talents toward writing about architecture, and it would be interesting to compare his articles of this period to The Canadian Architect and Builder's articles, to see if they are stylistically similar and if he alone was the anonymous editor. ${ }^{32}$ The vehemence with which the editor attacked the whole process of Queen's Park throughout its inception makes it highly likely that the author had a serious gripe to bear with the competition, the architect, and the chosen design. Staying anonymous would eliminate any personal recriminations directed toward the author, who would most surely be accused of seeking revenge for losing the competition.

The building opened to great fanfare in April 1893 (fig. 10). Large crowds turned out to tour the building's interior that had remained a mystery throughout construction. No mention can be found of the architect being present on the occasion, nor the firms that missed out on the commission. Waite likely wished to wash his hands completely of the whole affair, and his adversarial dealings with Fraser. The winning architects of the competition were not personally heard from, but The Canadian Architect and Builder 


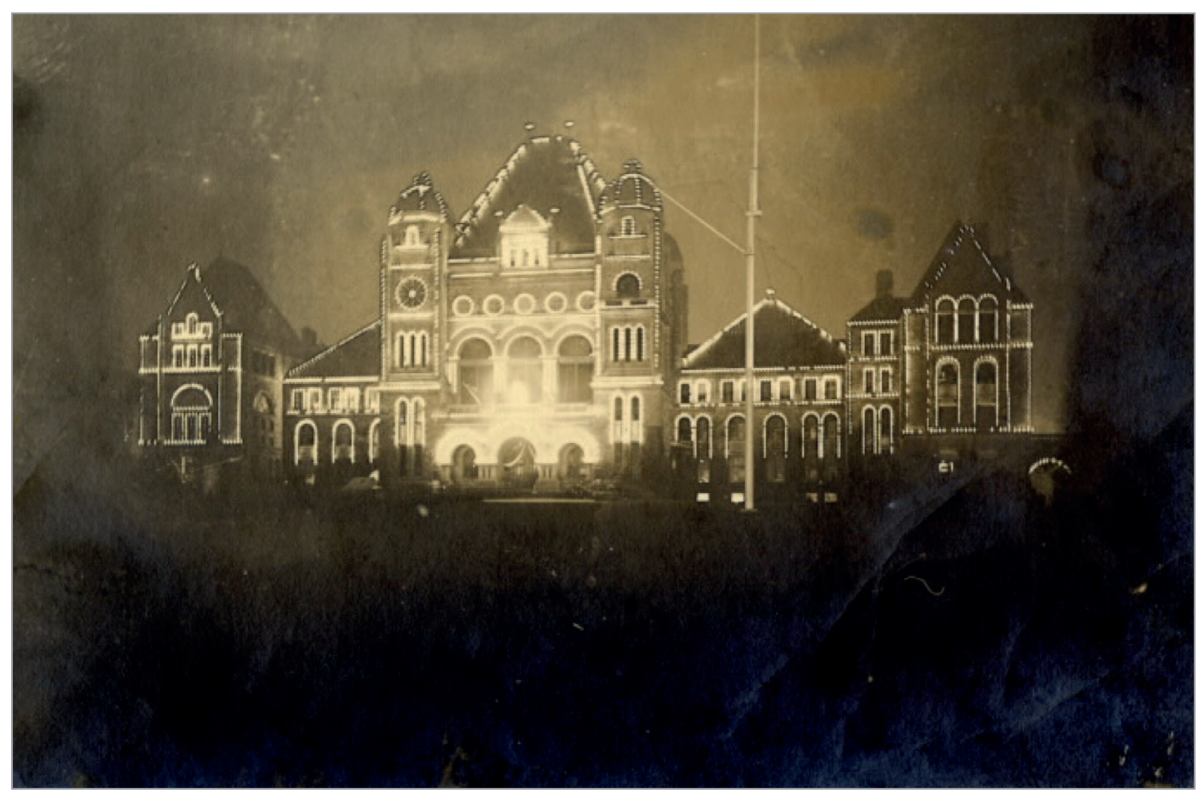

FIG. 10. PARLIAMENT BUILDING LIT UP IN 1900. | COURTESY OF THE TORONTO PUBLIC LIBRARY.

voiced a strong opinion, at first complimentary, but eventually critical, reducing the design to the talents of an unskilled draftsman, albeit declared anonymously. ${ }^{33}$ This was a considered dig at not only the design implemented, but the architect as well, with hints being dropped that he was not personally involved with the majority of the design.

The fledgling OAA was gaining acceptance and the controversy that necessitated its inauguration was a direct result of the events surrounding Queen's Park. In the first five years of its existence, architects involved in the Legislative Building controversy, Curry, Darling, and Gordon, were elected as presidents, a most telling connection that links the disgruntled architects with the Parliament Building, and the creation of the OAA.

\section{CONCLUSION}

The solid building of today has lost its taint of scandal and stands as an imposing testament to a short, but impressive stylistic era in Toronto, and the world. A tourist attraction now, it is a tribute to Waite and the craftsmen who were given free reign with the sculptural details that adorn every façade of the building and interior woodwork. The sculpture alone, both inside and outside the building, conceptually designed by the architect, ensure that Queen's Park remains one of the most impressive examples of medievally styled sculpture on this side of the Atlantic. The sculpture adds a finesse to the now asymmetrical building, which alone serves to justify the choice of Waite as the architect. ${ }^{34}$ The fledgling association that grew out of the debacle of the competition went on to eventually regulate and ensure that the quality of work emanating from Ontario architects was not considered inferior to that of foreign architects. The OAA, created out of necessity against foreign incursions, almost floundered after the initial impetus to form. Early rebellion arose from some practicing the profession in the province, who objected to the stringent new guidelines and demands of excellence which now required exams to become a member. ${ }^{35}$ The vociferous critiques of potential associates, and their unwillingness to abide by the restrictions instigated and eventually legislated, almost ended the association, before it began. It nevertheless survived and to this day regulates the practice of architecture in Ontario, and it ensures that foreign architects must be affiliated with existing local firms. The Legislative Building will likely stand for another hundred years as a legacy to the now almost forgotten architect, and the scathing critique that it will be "one of the ugliest and most inartistic buildings erected on this continent" holds little credence today. ${ }^{36}$ The mishandled competition is now forgotten, and the legacy of the architects involved is limited to their designs that still stand in the city. The controversy is forgotten as well and the building can now truly be admired for its distinctive Romanesque style that escaped the wreaker's ball, in a city that proliferates in contemporary high-rise constructions.

\section{NOTES}

1. "The New Parliament Building," 1888, The Canadian Architect and Builder, July, p. 6.

2. Dale, Clare A., 1993, The Palaces of Government: A History of the Legislative Buildings of the Provinces of Upper Canada, Canada and Ontario, 1792-1992, Toronto, Ontario Legislative Library.

3. Arthur, Eric Ross, 1979, From Front Street to Queen's Park: The Story of Ontario's Parliament Buildings, Toronto, McClelland and Stewart.

4. Hall, Roger, 1993, A Century to Celebrate, 1893-1993: The Ontario Legislative Building / Un centenaire à fêter, 1893-1993: L'édifice de I'Assemblée législative de l'Ontario, Toronto, Legislative Assembly of Ontario.

5. Dendy, William, 1993, Lost Toronto: Images of the City's Past, Toronto, McClelland \& Stewart.

6. Hall, A Century to Celebrate, op. cit., p. 8.

7. Dendy, Lost Toronto, op. cit., p. 52-55. 
8. Osbaldeston, Mark, 2008, Unbuilt Toronto: A History of the City that Might Have Been, Toronto, Dundurn Press.

9. Ontario, Sessional Papers of the Legislative Assembly of the Province of Ontario, vol. 12:4, 1880, no. 52, Reports of the Public Works Architect, and Other Papers.in Relation to Parliament and Departmental Buildings, Toronto, Queen's Printer.

10. Dale, The Palaces of Government, op. cit., p. 48.

11. Tully had already designed Trinity College on Queen St., St. Catherine's Town Hall, Coburg's Victoria Hall, as well as the Bank of Montreal at Front and Yonge streets.

12. Osbaldeston, Unbuilt Toronto, op. cit., p. 63.

13. Arthur, From Front Street to Queen's Park op. cit., p. 52.

14. Ibid.

15. Osbaldeston, Unbuilt Toronto, op. cit., p. 66.

16. Ibid.

17. Ibid.

18. Arthur, From Front Street to Queen's Park, op. cit., p. 61.

19. Id., p. 55.

20. Arthur, From Front Street to Queen's Park, op. cit., p. 53.

21. Crossman, Kelly, 2014, Architecture in Transition: From Art to Practice, 1885-1906, Montreal, McGill-Queen's University Press.

22. Arthur, From Front Street to Queen's Park, op. cit., p. 56.
23. Id., p. 57.

24. Ibid.

25. Crossman, Architecture in Transition, op. cit., p. 15.

26. Ibid.

27. Arthur, From Front Street to Queen's Park, op. cit., p. 50

28. Legislative Assembly of Ontario, [https:// www.ola.org], accessed September 9, 2019.

29. Arthur, From Front Street to Queen's Park, op. cit., p. 54.

30. Id., p. 59.

31. Ibid.

32. Hill, Robert, n.d. "Curry, Samuel George," Biographical Dictionary of Architects in Canada, 1800-1950, [http://dictionaryofarchitectsincanada.org/node/1634], accessed March 24, 2020.

33. "The New Parliament Building," 1893, The Canadian Architect and Builder, April, vol. 6, p. 47.

34. The building was originally symmetrical, but a redesign by Edward James Lennox after the 1906 fire changed the south façade.

35. Crossman, Architecture in Transition, op. cit., p. 55-56.

36. "The New Parliament Building," 1988, op. cit., p. 6. 